\title{
Tectonic significance of Intraoceanic Faults in the Nankai Trough: Implications for inter- and intra-plate earthquakes
}

\author{
Takeshi TSUJI ${ }^{1}$, Shuichi KODAIRA ${ }^{2}$, Jin-Oh PARK ${ }^{3}$, \\ Juichiro $\mathrm{ASHI}^{3}$ and Toshifumi MATSUOKA ${ }^{1}$ \\ ${ }^{1}$ Dept. of Civil and Earth Res. Eng., Kyoto University \\ ${ }^{2}$ Japan Agency for Marine Earth Science and Technology (JAMSTEC) \\ ${ }^{3}$ Ocean Research Institute, University of Tokyo
}

\begin{abstract}
Seismic reflection studies have been intensively carried out in the Nankai Trough region. However, the role of oceanic crust was not well understood in the plate convergent margin. Recently, Tsuji et al. [2009] identified intraoceanic faults developed as imbricate structures within the subducting Philippine Sea plate off the Kii Peninsula in central Japan manifesting as strong-amplitude reflections observed in an industry-standard 3D seismic reflection data set. Here we use several 2D and 3D seismic reflection data acquired in the whole Nankai Trough region in order to discuss characteristics of intraoceanic faults distributed in the Nankai Trough region. Seismic profiles demonstrate that intraoceanic faults are densely distributed in the Nankai Trough east of the Cape Shionomisaki. Large displacements of a major intraoceanic faults elevate the crust surface, and the offset due to cumulative displacements reaches $>1 \mathrm{~km}$. These imbricate intraoceanic faults cut through the oceanic crust as a discontinuous thrust plane. The intraoceanic faults strike nearly parallel to the trend of the trough axis. However the fault traces are bending at the western termination; the fault planes extend upward from side edges of the underlying intraoceanic faults and work as lateral faults. The deformation along the intraoceanic faults may have continued until recently because the shallow sediment as well as the seafloor is deformed due to the fault displacement. Furthermore, the locations of the intraoceanic faults recognized in the seismic data are distributed around the estimated hypocenters of the mainshocks and aftershocks of the 2004 intraplate earthquakes $(\mathrm{Mw}>7)$, and their geometry extracted from the 3D seismic data could explain the kind of complex rupture pattern observed during the 2004 events. These observations demonstrate that the intraoceanic faults should be seismogenically active. Furthermore the segmentation of interplate earthquake off the Cape Shionomisaki is consistent with the ridge originated by the displacement of intraoceanic fault. Because the displacement along the intraoceanic fault is developed with subduction and cuts the plate boundary faults due to their dynamic displacements, there is a possibility that the intraoceanic faults control the interplate earthquake segmentation.
\end{abstract}

\section{INTRODUCTION}

The Nankai Trough is a convergent margin where the Philippine Sea plate is subducting beneath southwest Japan. Because this subduction zone has repeatedly generated great earthquakes with $\mathrm{Mw}>8^{1}$, seismic reflection studies have been intensively carried out in the whole Nankai Trough region (Figure 1) and characteristics of the seismogenic faults have been revealed 2) 3) 4). However, the role of oceanic crust in this plate convergent margin was not well understood. Recently, the intraoceanic faults developed as imbricate structures within the subducting Philippine Sea plate off the Kii Peninsula in central Japan were identified from an industry-standard 3D seismic reflection data set ${ }^{5)}$. Furthermore the intraplate earthquakes were frequently observed for the past few years (e.g., 2004 earthquake off the Kii peninsula; 2009 earthquake off the Tokai region). Therefore the characterization of these intraoceanic faults is important for the earthquake prevention. Furthermore because the faults cutting the entire crust serve as conduits for bringing water to the oceanic crust and upper mantle, the faults may be related to the mantle serpentinization ${ }^{6}$. Here we use several 2D/3D seismic reflection data acquired in the whole Nankai Trough region (Figure 1) and extract geometries of (1) intraoceanic faults, (2) surface of oceanic crust and (3) Moho in order to discuss a role of intraoceanic faults distributed in the Nankai Trough region. 


\section{SEISMIC REFLECTION DATA}

In this study, we use 2D and 3D multi-channel seismic reflection data acquired by JAMSTEC (Figure 1). Since the reflection strength of intraoceanic faults and Moho are weak, we calculated several seismic attributes ${ }^{7)}{ }^{8)}$ in order to extract their geometries (Figure 2). Furthermore, although the reflection signal of intraoceanic faults and Moho is weak, we try to find the intraoceanic reflections from 2D seismic data by comparing with the high-resolution 3D seismic reflection data (Figures 2a and 3) ${ }^{5}$.

\section{INTRAOCEANIC FAULTS}

Seismic profiles demonstrate that intraoceanic faults are densely distributed in the Nankai Trough east of the Cape Shionomisaki (Figure 1). Large displacements of major intraoceanic faults elevate the crust surface, and the offset due to cumulative displacements reaches $>1 \mathrm{~km}$ at the sediment -igneous crust interface (Figure 2a). From our analysis, a part of Kashinozaki-Knoll ${ }^{9)}$ is also uplifted by the intraoceanic thrust displacement (Figure 2b). These imbricate intraoceanic faults cut through the oceanic crust as a discontinuous thrust plane ${ }^{5)}$. The faults (thrusts) further cut the Moho discontinuity (Figure 2b), as in the case of the outer-rise normal faulting ${ }^{6}$.

The intraoceanic faults are thrust fault and strike nearly parallel to the trend of the trough axis. However the fault traces are bending at the western termination; the fault planes extend upward from side edges of the underlying intraoceanic faults and work as lateral faults (Figure 3). Additional evidence of the existence of the lateral fault system is provided by microearthquake studies off the Kii Peninsula 10) 11), which show composite focal mechanisms with the N-S to NW-SE strike of the nodal plains.

Because we mainly used 2D seismic data in this study and their resolution is lower than 3D seismic data, it is difficult to extract intraoceanic faults with small-displacement (i.e., weak reflections). Although we only observed large (predominant) faults within oceanic crust on $2 \mathrm{D}$ seismic profile, the smaller faults as well as back thrusts are densely distributed between the large intraoceanic faults as recognized from 3D seismic data (Figure 3$)^{5 \text { ) }}$.

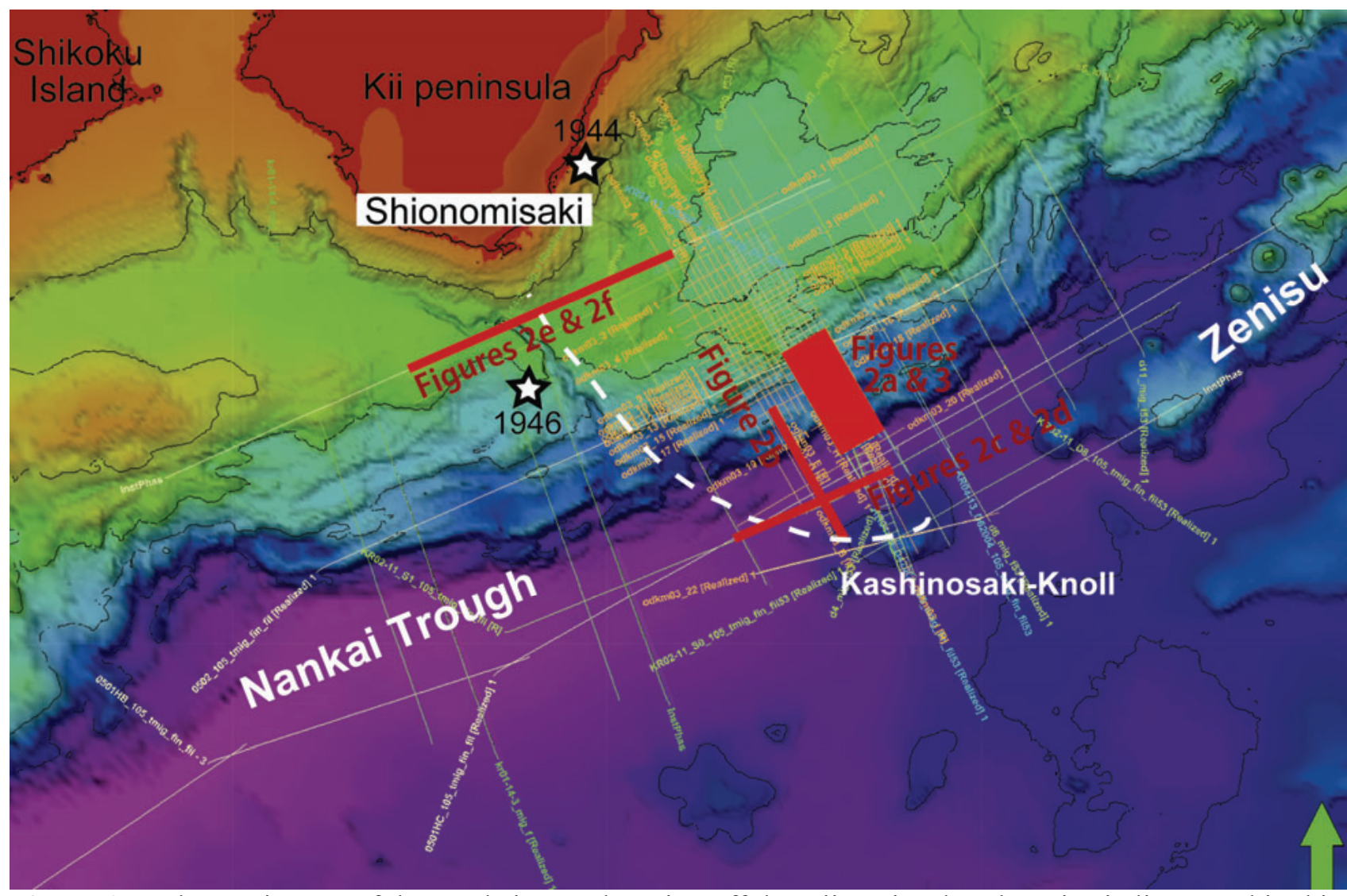

Figure 1. Bathymetric map of the Nankai Trough region off the Kii peninsula. The seismic lines used in this study are represented by thin lines. Thick red lines and rectangle indicate the locations of seismic profiles and 3D seismic survey area displayed in this paper respectively. White dashed line represents the crust surface trace of the large intraoceanic fault. 

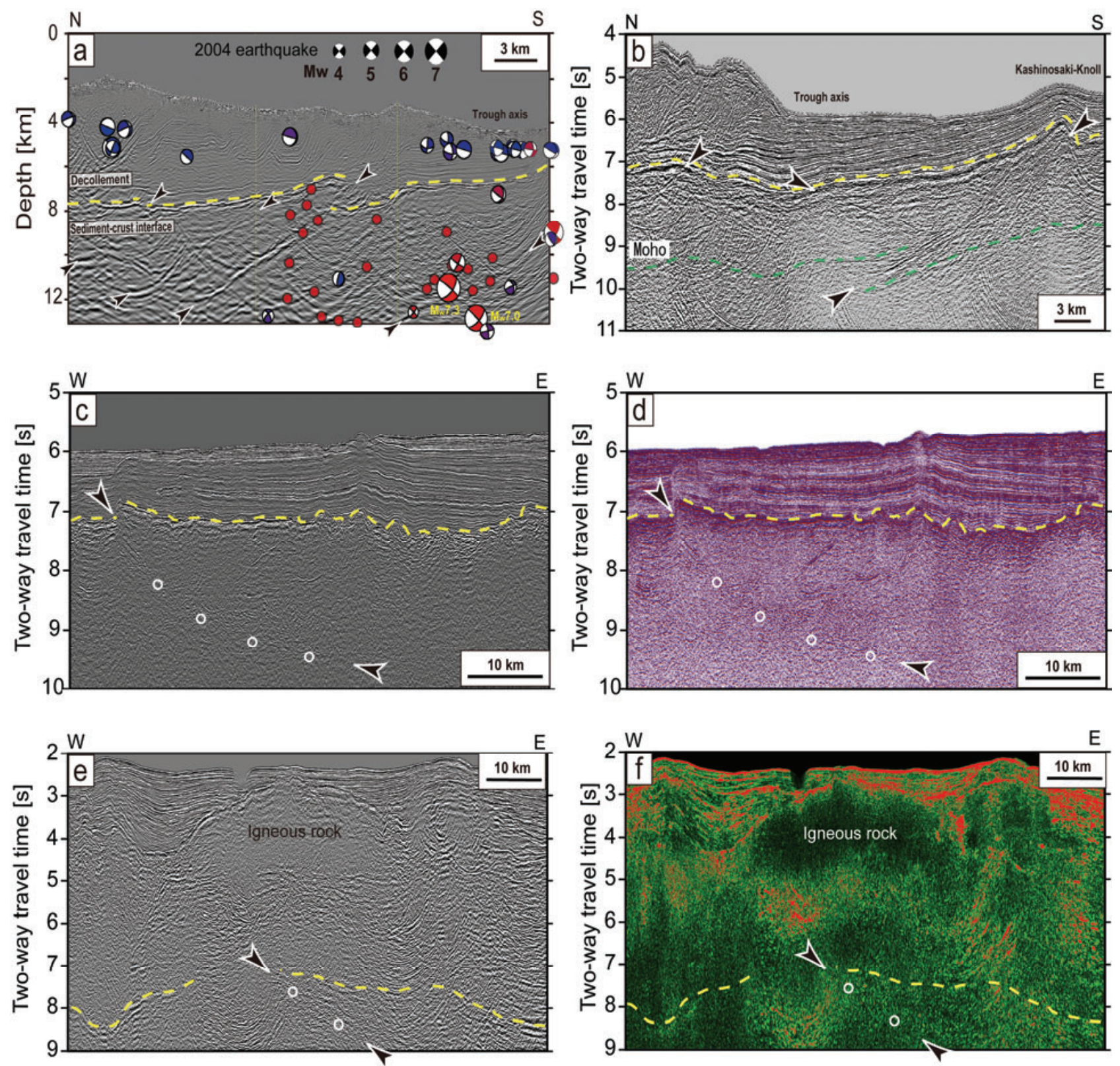

Figure 2. (a) Intraoceanic faults on the trough-perpendicular 3D high-resolution seismic profile. Black arrowheads represent intraoceanic faults. Yellow lines represent the sediment-igneous crust interface. On this profile, the hypocenters of 2004 earthquake as well as aftershock are displayed. Survey line location are described in Figure 1. (b) Large intraoceanic faults developed at the Kashinosaki-Knoll. Green dashed lines represent the Moho discontinuity. From this seismic profile, we recognize that the intraoceanic faults cut the Moho discontinuity. (c) Intraoceanic faults on the trough-parallel profile. (d) Amplitude weighted instantaneous phase of the seismic data of Figure 2c. (e) Intraoceanic faults with high-velocity dome off the Cape Shionomisaki. (f) Envelope of seismic data of Figure 2e. The high-velocity dome can be recognized as anomaly of low-reflection strength because of its homogeneous characteristics. 


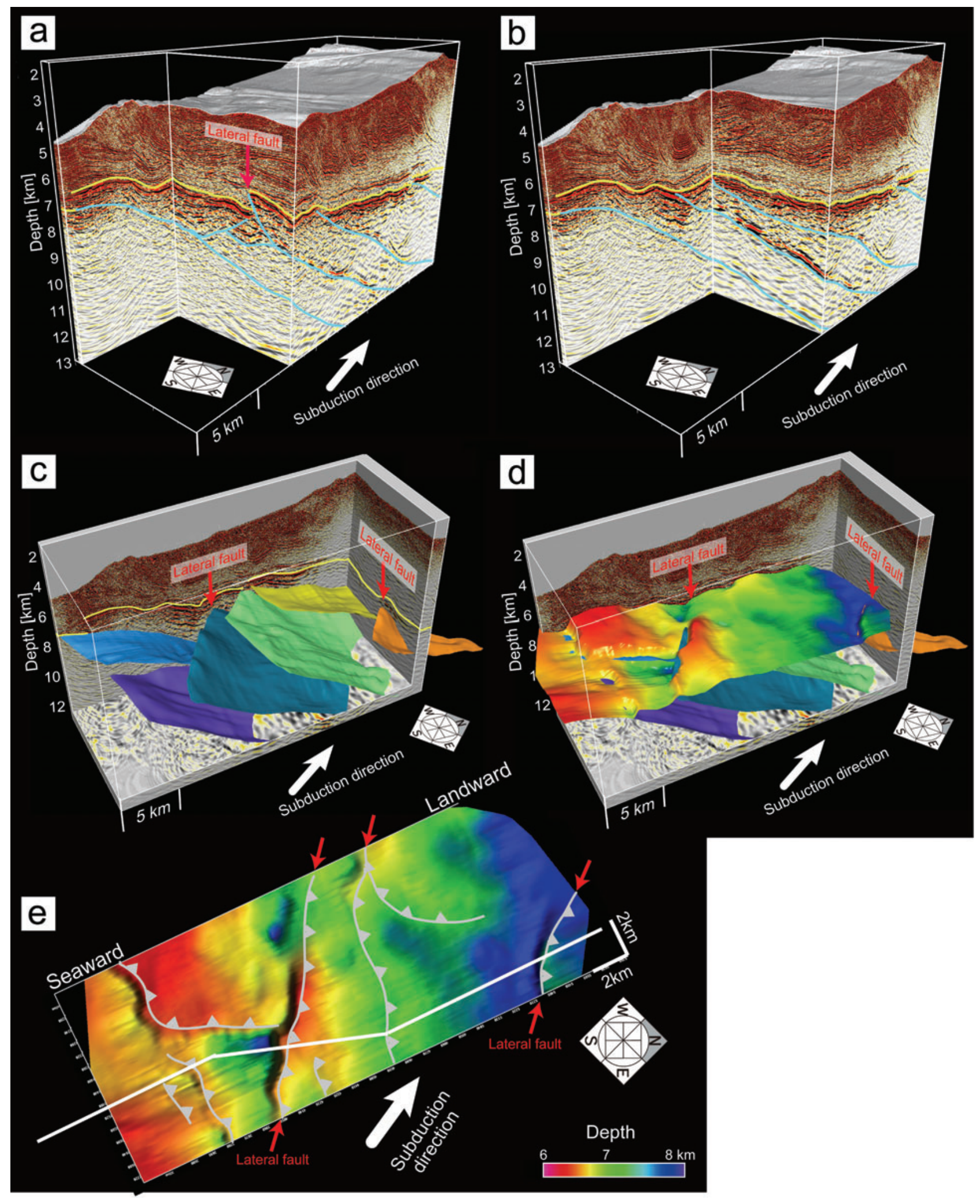

Figure 3. (a) \& (b) 3D prestack depth migrated volumes ${ }^{5}$. Blue lines show the intraoceanic thrusts that have strong and continuous reflections. Yellow lines represent the sediment-igneous crust interface. A lateral faults near the sediment-igneous crust interface are also shown (red arrows). (c) Geometry of intraoceanic thrusts. Almost all intraoceanic thrusts strike E-W and dip to the north. (d) Geometry of oceanic crust upper surface and intraoceanic thrusts. Colours of the crust surface represent depth. (e) Map view of the oceanic crust upper surface. Gray lines represent the traces of several intraoceanic thrusts at the crust surface. The white line shows the location of the seismic profile displayed in Figure 2a. 


\section{EARTHQUAKE ACTIVITIES OF INTRAOCEANIC FAULTS}

The deformation within oceanic crust may have continued until recently with subduction of Philippine Sea plate because the shallow sediment as well as the seafloor is deformed due to the thrust displacement (Figure 2b) ${ }^{5)}{ }^{12}$. Furthermore, the locations of the intraoceanic faults recognized in the seismic data are distributed around the estimated hypocenters of the two mainshocks $(\mathrm{Mw}>7)$ and aftershocks of the 2004 intraplate earthquakes off the Kii Peninsula 13) 14), and their geometry extracted from the 3D seismic data could explain the kind of complex rupture pattern observed during the 2004 events (Figure 3) ${ }^{5)}$. Although normal fault events are expected within the shallow oceanic crust in the trench - outer-rise region ${ }^{6)}{ }^{15)}$, reverse faults in relatively shallow oceanic crust were responsible for the 2004 earthquake off the Kii Peninsula (Figure 2a). The compressive stress for reverse fault may accumulate in shallow oceanic crust when the slip is locked on the subduction interface ${ }^{13) 16)}$.

On 11 August 2009, another large intraplate earthquake was occurred in the Nankai Trough off the Tokai area ${ }^{17)}$ and generated strong ground motions on the islands of Japan, because the rupture fault was located near the Japanese coast. Obana et al. ${ }^{11)}$ further revealed the micro-earthquakes within the subducting Philippine Sea plate using the ocean bottom seismographs (OBS). These observations demonstrate that these intraoceanic faults should be seismogenically active.

The longest crust surface trace of the intraoceanic fault we revealed in this study is extending to $\sim 100 \mathrm{~km}$ (Figure 1). Therefore if the large intraoceanic faults we revealed in this study are ruptured, it may generate strong ground motion to Japan Island.

\section{VARIATION OF INTRAOCEANIC FAULTS AND INTERPLATE EARTHQUAKE}

The intraoceanic faults are densely distributed eastern side of the Cape Shionomisaki. On the other hand, the intraoceanic faults with large displacement are sparsely distributed western side of the Cape Shionomisaki. The variation in fault density may be related to the state of stress within the oceanic crust; therefore Cape Shionomisaki (Kii peninsula) works as a boundary of stress state ${ }^{6}$.

The interplate earthquake segmentation off the Shionomisaki (i.e., segmentation between 1944 Tonankai and 1946 Nankai earthquakes) ${ }^{1)}$ is consistent with the ridge originated by the displacement along intraoceanic fault (white dashed line in Figure 1). Therefore there is a possibility that the intraoceanic faults control the interplate earthquake segmentation; the displacement along the intraoceanic fault is developed with subduction and cuts the plate boundary faults due to their dynamic displacements. Actually the angle of plate boundary is much changed at the central Kii peninsula (Shionomisaki) ${ }^{18)}$; the faults within subducting Philippine Sea plate make possible to induce the change in the subducting angle of Philippine Sea plate.

On the seismic profile (Figure 2e), the large intraoceanic fault is identified below the high-velocity body $(\sim 6.2 \mathrm{~km} / \mathrm{s})$ estimated by the seismic refraction survey ${ }^{12)}$. The high-velocity body can be recognized as homogeneous dome (blight zone) on the envelope profile (Figure 2f). The high-velocity body may be intruded igneous rock because the igneous rock was observed at the onshore outcrop (Shionomisaki igneous complex) north of this high velocity body ${ }^{19}$. A small outcrop of acidic rocks (the Kumano plutonic rocks) is further observed at $10 \mathrm{~km}$ off the Shionomisaki [Geological Survey of Japan, 1997]. This outcrop is interpreted to have been intruded into the overriding sedimentary wedge soon after the subduction of the Shikoku Basin started ${ }^{20}$. If the high-velocity body in the overriding plate generates compressive stress due to high friction at the plate interface ${ }^{16)}$, the lateral- and reverse-faults are likely to grow with subduction (Figure 4).

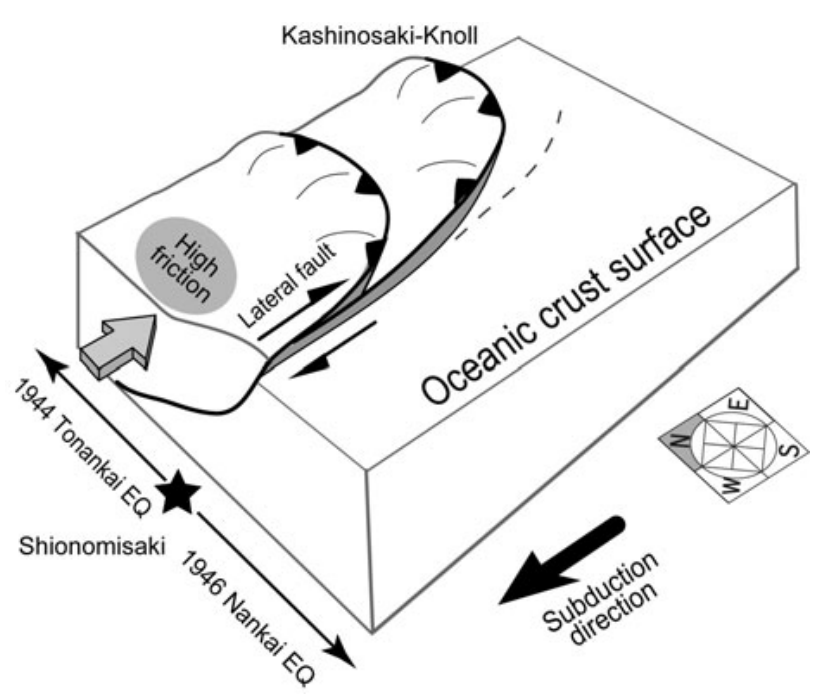

Figure 4. Schematic image of the intraplate faults developed off the Shionomisaki. This intraoceanic fault locates near the hypocenters of the 1944 Tonankai Earthquake and 1946 Nankai Earthquake (black star). 


\section{SUMMARY}

1. We identified intraoceanic faults developed as imbricate structures within the subducting Philippine Sea plate in the Nankai Trough.

2. The intraoceanic faults are distributed around the hypocenters of the first mainshock and aftershocks of the 2004 earthquake. Because the intraoceanic fault geometries are consistent with the focal mechanism of the first mainshock, we believe that the thrusts with similar characteristics have slipped during the first mainshock.

3. The cumulative displacements inferred from deformation at the crust surface suggest that there is potential for periodic earthquakes, similar to the 2004 earthquake, to occur in the future.

4. The displacement along the intraoceanic fault is developed with subduction process and cuts the plate boundary faults due to their dynamic displacements. Therefore there is a possibility that the intraoceanic faults control the segmentation of interplate earthquake (i.e., the boundary between Tonankai and Nankai earthquakes).

ACKNOWLEDGMENT: We used seismic data acquired by JAMSTEC. This research was supported by Mitsubishi Foundation (natural science).

\section{REFERENCES}

1) Ando, M., 1975, Source mechanisms and tectonic significance of historical earthquake derived from tsunami data, Phys. Earth Planet. Inter., 28, 320336.

2) Moore, G.F., Shipley, T.H., Stoffa, P.L., Karig, D.E., Taira, A., Kuramoto, S., Tokuyama, H., and Suyehiro, K. (1990), Structure of the Nankai Trough accretionary zone from multichannel seismic reflection data, J. Geophys. Res., 95, 8753-8765.

3) Park, J.-O., Tsuru, T., Kodaira, S., Cummins, P.R., and Kaneda, Y., 2002, Splay fault branching along the Nankai subduction zone, Science, 297, $1157-1160$.

4) Tsuji, T., Tokuyama, H., Costa Pisani, P., and Moore, G., 2008, Effective stress and pore pressure in the Nankai accretionary prism off the Muroto Peninsula, southwestern Japan, J. Geophys. Res., 113, B11401, doi:10.1029/2007JB005002.

5) Tsuji, T., Park, J.-O., Moore, G., Kodaira, S., Fukao, Y., Kuramoto, S., and Bangs, N., 2009, Intraoceanic Thrusts in the Nankai Trough off the Kii Peninsula: Implications for Intraplate Earthquakes, Geophys. Res. Lett., 36, L06303, doi:10.1029/2008GL036974.

6) Ranero, C.R., Morgan, J.P., Mclntosh, K., and Relchert, C., 2003, Bending-related faulting and mantle serpentinization at the Middle America trench, Nature, 425, 367-373.
7) Taner, M. T., Koehler, F., and Sheriff, R.E., 1979, Complex seismic traces analysis, Geophysics, 44, 1041-1063.

8) Tsuji, T., Nakamura, Y., Tokuyama, H., Coffin, M.F., and Koda, K., 2007, Oceanic crust and Moho of the Pacific Plate in the eastern Ogasawara Plateau region, Island Arc, 16, 361-373.

9) Ike, T., Moore, G., Kuramoto, S., Park, J.-O., Kaneda, Y., and Taira, A., 2008, Tectonic and sedimentation around Kashinosaki Knoll: A subducting basement high in the eastern Nankai Trough, Island Arc, 17, 358-375.

10) Obana, K., Kodaira, S., Kaneda, Y., Mochizuki, K., Shinohara, M., and Suyehiro, K., 2003, Microseismicity at the seaward updip limit of the western Nankai Trough seismogenic zone, $J$. Geophys. Res., 108, 2459, doi:10.1029 /2002JB002370.

11) Obana, K., Kodaira, S., and Kaneda, Y., 2005, Seismicity in the incoming/subducting Philippine Sea plate off the Kii Peninsula, central Nankai trough, J. Geophys. Res., 110, B11311, doi:10.1029 /2004JB003487.

12) Kodaira, S., Hori, T., Ito, A., Miura, S., Fujie, G., Park, J.-O., Baba, T., Sakaguchi, H., and Kaneda Y., 2006, A cause of rupture segmentation and synchronization in the Nankai trough revealed by seismic imaging and numerical simulation, $J$. Geophys. Res., 111, B0901, doi:10.1029 /2005JB004030.

13) Park, S.C. and Mori, J., 2005, The 2004 sequence of triggered earthquakes off the Kii peninsula, Japan, Earth Planets Space, 57, 315-320.

14) Ito, Y. et al., 2005, Spatial distribution of centroid moment tensor solutions for the 2004 off Kii peninsula earthquakes, Earth Planets Space, 57, 351-356.

15) Seno, T., and Yamanaka, Y., 1996, Double seismic zones, compressional deep trench-outer rise events and superplumes, in Subduction Top to Bottom, edited by Bebout, G.E., Scholl, D.W., Kirby, S.H., and Platt, J.P. Geophys. Monogr., AGU, Washington D.C., 96, 347-355.

16) Christensen, D., and Ruff, L.J., 1988, Seismic coupling and outer rise earthquakes, J. Geophys. Res., 93, 13,421-13,444.

17) National Research Institute for Earth Science and Disaster Prevention (NIED), 2009, http://www.hinet.bousai.go.jp/

18) $\mathrm{Xu}$, J., and Kano, Y., 2002, Geometry of slab, intraslab stress field and its tectonic implication in the Nankai trough, Japan, Earth Planets Space, 54, 733-742.

19) Miyake, Y., 1988, Petrology of the Shionomisaki igneous complex, Southwest Japan and its implication for the ophiolite generation, Marine Geology, 12, 283-302.

20) Miyake, Y., and Hisatomi, K., 1985, A Miocene forearc magmatism at Shionomisaki, southwest Japan, in Formation of Active Ocean Margins, Adv. Earth Planet. Sci., edited by N. Nasu, pp. 411-422, Springer, New York. 